\title{
A POSSIBILIDADE DA UNIFICAÇÃO DO DIREITO PRIVADO HISPANO-LUSO-ÄMERICANO
}

\author{
Oscar Martins Gomes \\ Professor de Direito Internacional Privado da \\ Faculdade de Direito da Universidade do Paraná.
}

1. - O II Congresso Hispano-Luso-Americano de Direito Internacional, reunido em São Paulo, como uma das primeiras comemorações do IV Centenário da Fundação dessa importante metrópole, traz no seu temário, aprovado em sessão preparatória de Coimbra, Portugal, e na resenha dos títulos das comunicações científicas admitidas, menção de assuntos que bem informam das características do magno conclave em relação ao âmbito da coletividade étnica e espiritual, que abrange.

Assim, quando o Congresso se propõe debater questões concernentes à nacionalidade na comunidade hispano-luso-americana ou procura para esta um sistema uniforme de regras de conflito de jurisdição, bem como quando cuida da unificação do direito privado hispano-luso-americano, e da proteção internacional dos direitos humanos na mesma comunidade, circunscreve o trato de tais assuntos ao grupo latino dos países que o Congresso compreende na sua denominação. Mas, amplia esse núcleo e abrange toda a latinidade ao submeter ao seu alto exame a união latina como fator de equilíbrio na sociedade internacional. E alarga enormemente seus objetivos, nos domínios jurídico e humano, ao sugerir a reforma da carta das Naȩõès 
Unidas, ao abordar os problemas de direito internacional marítimo, fluvial e aeronáutico, os direitos fundamentais do homem de acôrdo com o direito internacional, o código de delitos contra a paz e a segurança da humanidade, a guerra fria e a guerra psicológica.

2. - Ater-nos-emos, entretanto, no presente estudo, dentro da latinidade, ao grupo abrangido pela denominação do Congresso, no intuito de examinar a possibilidade da unificação do direito privado hispano-luso-americano.

Há que partir do direito comparado como elemento do direito positivo, na sua função prática de aplicação do direito. Espanha, Portugal, Brasil, Argentina, México e demais países da América latina, pela sua formação histórica, social, etnológica e cultural, afirmam já de si um elevado gráu de afinidade através do tempo e do espaço, de modo a tal circunstância alimentar a esperança da unidade almejada, o quanto possível.

LAMBERT destaca duas concepções suas: ao considerar o direito comparado como ciência social, visando à comparação de legislações as mais opostas, e ao tomar o direito comparado como elemento positivo para exame do direito comum legislativo. Nêste caso, a comparação deverá exercer-se entre sistemas jurídicos ligados entre si pelos laços de parentesco.

Mas êsse parentesco poderá advir da identidade de raça ou expressar-se pela filiação à mesma cultura, à influência histórica de igual civilização, atingida já no mesmo gráu de intensidade. Na primeira hipótese, olhando a comum descendência étnica, as legislações do grupo de países latinos oferece campo propício ao estudo comparativo. Na segunda hipótese, de semelhança cultural, adquirida, através de análogos estágios na marcha da história, a comparação poderá ser levada a efeito entre as legislações, por exemplo, dos países do conjunto germânico e as dos países do grupo latino, consoante indicou aquele autor.

Ora, a tarefa se torna tanto menos eivada de dificuldades si considerarmos apenas os sistemas legislativos do grupo latino, isto é, daqueles povos de origem comum pelo sangue e su- 
jeitos às múltiplas influências semelhantes dos fatores históricos, da religião, das idéas morais, dos costumes, da tradição.

No conceito de Guglielmo Ferrero, o que distingue essencialmente o espírito latino é a ordem, a harmonia, a medida. $\mathbf{E}$ isso a par do idealismo, do ansêio filosófico, da pesquisa científica, do culto da beleza e do sentimento de piedade. E no dizer de André Siegfried, as nações dêsse bloco são latinas, porque falam línguas românicas, instrumentos de certa expressão do pensamento, que correspondem indiscutivelmente a uma civilização, que tem por bêrço o Mediterrâneo e se impôs no surto luminoso da Renascença.

Acentua-se assim, cada vez mais, no decurso dos séculos, a poderosa influência do gênio greco-romano, ressaltado em tamanhas manifestações da grandeza do espírito, na filosofia, nas ciências, na política, no direito, nas artes.

3. - Por iniciativa do Govêrno do Brasil, através do Ministério das Relações Exteriores, do qual era então eminente titular o dr. João Neves da Fontoura, reuniu-se há dois anos, no Rio de Janeiro, o I Congresso da União Latina.

Entre as suas deliberações, aprovou o Congresso o projeto brasileiro de bases, reconhecendo a importância do papel histórico que os povos de origem latina desempenharam na evolução das idéias e no desenvolvimento da civilização do mundo, e afirmando os laços que os unem para salvaguarda dêsse patrimônio comum. Em consequência, recomendou aos Govêrnos e aos Povos Latinos, no interêsse da necessidade de consolidar a União Latina, os seguintes objetivos: - a) - assegurar a salvaguarda dos princípios sôbre que repousam a civilização latina e os estilos de vida e pensamento que constituem suas características essenciais; b) - favorecer os laços espirituais e o intercâmbio intelectual entre os povos latinos.

Ainda na Declaração de Direitos do Rio de Janeiro, formulada pela delegação brasileira e aprovada pelo Congresso, reafirmou êste sua fé na supremacia dos valores espirituais que constituem o acêrvo da civilização humanista e cristã das nações. 
A propósito das objeção do delegado do México quanto à expresão "cristã", baseado no princípio constitucional de liberdade de culto em seu país, propondo fosse substituida pela palavra "mediterrânea", o embaixador Raul Fernandes com acêrto explicou que a idéia cristã não importava em afirmação de princípio religioso, mas se fundava na circunstância de haver sido o cristianismo, históricamente, uma das fontes da latinidade, que nêle se impregnara de forma integral.

Entre as propostas votadas pelo I Congresso são de destacar a que recomenda a colaboração da União Latina com as Nações Unidas, a que cria um Centro de Altos Estudos Latinos, com sede em Roma, e a que cria três institutos: um do Direito Comparado em Paris, sede do Secretariado Geral da União Latina; um de História Latino-Americana, com sede em Sevilha, e um Instituto Latino de Estudos Geográficos, com sede em Lisboa.

4. - Com tais referências, ficam delineadas mais à evidência as características do grupo latino, inclusive a França, a Italia e a Rumânia. E mais ainda se fazem notar no conjunto dos países da América Latina, na Espanha, em Portugal e nas Filipinas, em virtude de cujas afinidades mais estreitas se reunem êles agora em Congresso visando os objetivos já assinalados de início.

De Espanha e Portugal, na sua continuidade territorial em tôda a península ibérica, partiram os navegantes que descobriram os novos mundos do outro hemisfério, e o repartiram entre si, sendo de lembrar, neste ensejo, o meridiano alexandrino do tratado de Tordesillas, tendente a delimitar as terras destinadas a um e outro dêsses países na América do Sul, mas rompida e de muito ultrapassada para oeste pelas façanhas dos homeriadas paulistas, nas suas intrépidas bandeiras.

Aos liames que unem as duas nações peninsulares, na sua destinação histórica, há a acrescentar a próxima semelhança das suas línguas, adotadas igualmente nos países que colonizaram. 
Quando as similitudes são de tal ordem e encontram ainda a reforçá-las a continuidade territorial, ocorre, para fortalecimento do conjunto, a unificação sob uma única sobérania, como aconteceu, na segunda metade do século XIX, com a Itália, em que Mancini levantou o lábaro incentivador da nacionalidade como princípio justificativo, e com a Alemanha, do tempo de Bismarck, a qual, ainda pouco antes da última guerra mundial, levou a efeito a anexação de outros países, depois dela desligados.

Independentemente da ocurrência da unificação, países de parentesco mais chegado assinam comumente pactos de direito privado, como algumas convenções ibéricas, entre Portugal e Espanha, ou inter-escandinavas, entre a Suecia, a Noruega, a Dinamarca, a Finlândia e a Islândia.

5. - Afim de obviar as dificuldades "de diversitate legum", na esfera do direito privado entre diferentes sistemas legislativos, certas convenções internacionais realizam o que RAOUL DE LA GRASSERIE chama a unificação provisória, consistente em um corpo de regras para dirimir os conflitos de legislações, ou seja, um superdireito, destinado a dar solução aos problemas interespeciais para aplicação do direito substancial mais apropriado a cada caso.

Viria então mais tarde a unificação definitiva das leis das diferentes nações, primeiro as comerciais e as civis, depois as políticas e administrativas.

Assim, a convenção votada em Havana, no ano de 1928, entre quinze países americanos, e denominada Código Bustamante, de Direito Internacional Privado, constitui já exemplo da unificação provisória. E a convenção de 1930, de Genebra, contendo a Lei Uniforme sôbre letra de câmbio e nota promissória, é paradigma da unificação definitiva.

Representam tais tentames grande e significativo passo na uniformização almejada, não obstante as reservas feitas pelos países signatários em uma e outra dessas convenções, sendo que em Genebra foi ultimada ainda outra convenção destinada a 
regular certos conflitos de leis em matéria mesmo de títulos cambiais.

Das três vias distintas alinhadas por R. DEMOGUE para a unificação, quais sejam: a imitação, quando um Estado copia as leis do outro, a adoção pura e simples, por um Estado, da legislação do outro, e a que consiste em concessões recíprocas entre diversos Estados, - êste último caminho tem sido o adotado nas conferências internacionais.

6. - Consoante observa Fr. CONTUZZI, citado por ILMAR P. MARINHO, em países imbuidos da mesma cultura jurídica, matérias em que as questões se revestem de um caráter de universalidade, como as atinentes ao direito comercial, mórmente o direito marítimo, podem alimentar mais de perto a esperança da desejada uniformidade. E esta tem sido, por isso, posta em prática, como mostram as convenções acêrca do direito cambiário, que suscita, na sua feição abstrata, quase sòmente questões técnicas.

$\mathrm{E}$ a uniformidade em tais questões é possivel mesmo entre os países filiados ao Direito Romano e outros, como a Inglaterra, que elaborou um corpo de direito quase inteiramente liberto da paternidade romana, sendo a Europa e depois o resto do mundo cindidos em duas esferas de influência: uma abrangendo o mundo anglo-saxão, e outra, os demais países - esferas tão judiciosamente denominadas pelos juristas anglo-saxões de países do direito comum ("common law") e países do direito civil, segundo faz ver L. BAYALOVITCH.

0 sistema do direito comum predomina em todos os países de língua inglesa, a êles levado pelos colonizadores britânicos.

Mas, dentro do larguíssimo âmbito universal, outros sistemas abrangem esferas de reconhecida influência. ARMINJON enumera sete principais sistemas legais no mundo: o já mencionado sistema do direito comum; o de inspiração francêsa, estendendo-se a muitas partes da Europa, aos territórios franceses de ultramar e à América Latina; o derivado do direito alemão, compreendendo o direito civil suisso, copiado pelos 
códigos civis turco, japonês e siamês; os sistemaș escandinavo, russo, islâmico e índico.

7. - 0 ramo do direito quiçá mais difícil de unificação é o do direito de família, mais adstrito a costumes locais, crenças, preconceitos, tradições, com fundamento na maneira peculiar de sentir, pensar e agir, de cada povo, levando as legislações a encararem de modo diferente certos institutos jurídicos, erigidos a preceitos de ordem pública. Já não falando na monogamia, forma de organização da família adotada em todos os países do ocidente, note-se que o divórcio a vínculo não é aceito por tôdas as legislações daqueles que mantem entre si laços de estreita afinidade, em virtude dos mesmos influxos nas etapas de sua formação e de seu progresso.

No próprio Império britânico, não obstante o prestígio da "common law", há povos que, arraigados na sua tradição, adotam a poligamia.

A Conferência de Direito Internacional Privado de Haia, patrocinada pelo govêrno holandês, nas suas várias reuniões a partir de 1893, conseguiu pôr de acôrdo muitas nações acêrca do casamento, separação, divórcio, tutela e curatela.

Quando as nações não chegam a entendimento comum relativamente a certos pontos por motivos das causas particularíssimas já apontadas, a uniformização é forçada a abrir sensivelmente seus flacos às reservas inevitáveis, no sentido de ficar permitido aos Estados contratantes a liberdade legislativa quanto aos pontos da discordância, consoante tem acontecido.

8. - Por ocasião do IV Congresso da Associação Internacional de Advogados ("International Bar Association"), reunido em Madrid em julho de 1952, e do qual tivemos oportunidade de participar, integrando a delegação do Instituto dos Advogados Brasileiros, sob a chefia do professor Arnoldo Medeiros da Fonseca, o dr. MARIO MATTEUCCI, Secretário Geral do Instituto Internacional para a Unificação do Direito Privado, organização técnica intergovernamental, com sede em Roma, esclarece que o Instituto atravessa as diferentes etapas des- 
critas pelo professor BUTTERIDGE, da Cambridge University Pres, na sua obra "Direito Comparado", publicada em 1949. São elas: a etapa preparatória, que consiste em estudar do pon. to de vista comparativo a razão pela qual a unificação tem sido reputada necessária, e daí a conveniência de instalar em cada país um Comité Nacional de Direito Comparado, como o que, a propósito, existe no Rio de Janeiro, sob a douta presidência do professor HAROLDO VALLADÃO, para confronto das fontes de legislação estrangeira com a nacional e informar a respeito; a etapa formulatória, que consiste em esboçar 0 direito uniforme, por juristas e outros peritos profissionais, como os representantes de organizações comerciais internacionais; a etapa operativa, que compreende todos os trabalhos executados para a adoção de um direito uniforme esboçado e pode ser dividida em duas fases, - uma consulta preliminar aos organismos públicos interessados na unificação e uma apresentação do anteprojeto, para sua adoção, aos respetivos govêrnos, que poderá então ouvir a respeito os juristas e professores, através de suas associações e academias; e a etapa final, que consiste em apresentar o projeto a uma conferência diplomática, que deve ser precedida de reunião de Comités preparatórios, composta de representantes dos Govêrnos, para analisar cuidadosamente as emendas sugeridas, facilitando, por êsse modo, o trabalho da conferência.

Lembra o autor que a conferência diplomática não constitui o único meio para adoção de um direito uniforme pelos diversos Govêrnos. Por meio das leis tipo dá para alcançar um certo gráu de uniformidade sem o convênio internacional, como acontece na unificação escandinava. Êsse sistema, em que as leis tipo são postas em execução em diferentes países, oferece mais possibilidade naqueles de legislações semelhantes.

$\mathrm{Na}$ prática internacional do direito mercantil, principalmente na parte referente à venda de mercadorias, é frequente encontrarem-se cláusulas tipo, que facilitam o intercâmbio comercial.

9. - Muito teriamos a dizer sôbre lei modêlo e contrato tipo. Entretanto, não deve passar sem observação o fato de ha- 
ver países onde o direito privado interno não é uniforme e que lutam com as mesmas dificuldades que se notam no círculo internacional dos países. Tal se vê nos Estados Unidos, a cujos Estados federados é permitido legislar sôbre direito civil, comercial, penal e processual, com a agravante de que, em cada Estado, a última instância judiciária é a do seu próprio Tribunal, sem recurso para o Supremo Tribunal Federal. Alí, para minorar a divergência, a lei de um Estado, quando em condições de satisfazer aos interêsses gerais, tem sido copiada por outros Estados. E existe um Comité de Uniformidade de Decisões Judiciais, para obviar o inconveniente da falta de unidade legislativa e de interpretação de leis semelhantes pelos Tribunais.

Nos países de unidade legislativa, como o Brasil, tal problema não se apresenta. E para as divergências de interpretação da lei federal, entre Tribunais estaduais, aí está o salutar remédio do recurso extraordinário para o Supremo Tribunal Federal, visando à unificação do direito nacional.

10. - A divergência de leis e de sua aplicação constitue uma das inquietações de PASCAL, que perguntava: "Como explicar que o justo ou o injusto mudem de qualidade mudando de clima, que três graus de elevação do polo transtornem a jurisprudência, que um meridiano decida da verdade? A justiça é una e ela deveria ser observada em tôda parte do mesmo modo. Divertida justiça que um rio ou uma montanha limita. Verdade para cá dos Pirineus, êrro para lá!... ("PENSÉES").

Mas, outro filósofo francês, aprofundando o estudo das condições existenciais de cada povo, nas suas relações necessárias, MONTESQUIEU, o consagrado autor de "L'ÉSPRIT DES LOIS", afirmou: "As leis devem ser tão próprias do povo para a qual foram feitas que é muito raro o caso em que as de uma nação possam convir a outra".

Os esforços de unificação, para melhor e maior comunhão do direito na humanidade civilizada, como queria SAVIGNY, se encaminham no sentido justamente de conciliar as divergên- 
cias profligadas por um e justificadas por outro dos dois pensadores citados.

E a aproximação das legislações se mòstrará tanto mais realizável quanto mais acentuados forem os laços de parentesco entre os povos que as ditaram, como já se acentuou antes, à luz das judiciosas observaçóes de LAMBERT.

Eis porque a unificação do direito privado hispano-luso-americano, entregue, que seja, aos labores de um instituto próprio e seguindo as etapas preconizadas por BUTTERIDGE, se apresenta possível, gradativamente, nos vários ramos do Direito, de modo a fortalecer ainda mais a união entre êsses povos afins dentro da latinidade. 